\title{
AN EMPIRICAL ANALYSIS OF RELATIONSHIP BETWEEN SELECTED INDICATORS OF SUSTAINABLE DEVELOPMENT AND FINANCIAL DEVELOPMENT IN INDIA
}

\author{
NIHARIKA $^{1}$, SWATI SHASTRI $^{2}$ \& SHRUTI SHASTRI $^{3}$ \\ ${ }^{I}$ Research Associate, Department of Economics, Banasthali Vidyapith Rajasthan, India \\ ${ }^{2}$ Associate Professor, Department of Economics, Banasthali Vidyapith Rajasthan, India \\ ${ }^{3}$ Assistant Professor, Department of Economics, Banasthali Vidyapith Rajasthan, India
}

\section{ABSTRACT}

This study attempts to empirically examine the link between selected indicators of sustainable development and financial development (measured by a composite index) in India, during 1980 - 2011. Towards this objective, JohansenJuselius test of co integration and Granger Causality test have been used. The study finds existence of co integration between financial development and indicators of sustainable development in the presence of economic growth. Granger causality / Block Erogeneity Wald test shows that financial development causes life expectancy, and there exists bidirectional causal relationship between financial development and per capita income. Study finds weak direct causation from financial development to environmental outcomes and absence of causation between financial development and gross enrolment ratio. This study, therefore, recommends facilitation of financial sector development for the better health outcomes and reduction of poverty in the economy. However, financial development is not exogenous and is probably constrained by the level of poverty in the economy.

KEYWORDS: Financial Development, Principal Component Analysis, Johansen-Juseliuss Co Integration Test \& Granger Causality Test

Received: May 18, 2017; Accepted: Jun 10, 2017; Published: Jul 19, 2017; Paper Id.: IJECRAUG20177

\section{INTRODUCTION}

Sustainable development has been a matter of great concern for both developed and developing countries in the past two decades. Sustainability means, the ability to sustain and the capacity to endure, whereas the term development in itself comprises both qualitative and quantitative growth of economy. Precisely, sustainable development is a "development that meets the needs of the present without compromising the ability of future generations to meet their own needs". Since Brundtland Report (Brundtland Commission 1987), there are continuous attempts towards the conversion of economic development into sustainable development. However, it is quite expensive and tough path for the developing countries such as India to attain the goal of sustainable development.

Sustainable Development is a broad, complex \& comprehensive phenomenon, which includes various non economic and non quantifiable aspects of the economy, therefore, only few empirical researches have been contributed in the field of sustainable development. On the other hand, the role of financial development in field of economic growth is the issue of vast theoretical and empirical study, but very few studies examine the relationship between financial development and sustainable development. Recent studies conducted in the field of sustainable development laid stress on various ways to achieve sustainable development goals. Further, these studies explicate that financial 
sector development is one of the major contributors of sustainable development. The present study aims to analyse the causal relationship between financial development and selected indicators of sustainable development in India.

In particular, we focus on four indicators related to sustainable development goals namely, poverty, health, gender equality and climate change, out of the 17 goals proposed by United Nation (2015). Financial development has been measured by a composite index using Principal component analysis.

This paper is structured as follows, Section 2 reviews the theoretical and empirical literature related to the relationship between financial sector development and sustainable development. Section 3 discusses about data and methodology. Section 4 presents the empirical analysis; Section 5 concludes the findings of empirical estimation and provides policy implications.

\section{REVIEW OF THEORETICAL AND EMPIRICAL LITERATURE}

There is lack of theoretical direct linkages between financial development \& sustainable development, but there exist theoretical linkages between economic growth and sustainable development \& financial development and economic growth

Environment Kuznets curve shows the relationship between economic growth and environmental degradation. The Environment Kuznet Curve Hypothesis (EKC) implies that environmental impact indicator is an inverted U-shaped function of income per capita. This hypothesis shows relationship between environmental quality and economic development: various indicators of environmental degradation tend to get worse as economic growth occurs until average income reaches a certain point over the course of development.

The financial sector works parallel to the real sector and supports the economic growth process by boosting savings and investment process. Financial development mitigates the risk involved in the market. It efficiently transfers the resources from surplus sector to deficit sector to carry out the desired action for the growth. The efficient and developed financial sector is an essential condition to economic growth process.

Few empirical researches were conducted to analyse the role of financial development on environmental performance. Grossman and Krueger (1995), Claessens and Feijen (2007), Halicioglu (2009), Tamazian et al. (2009), Tamazian and Rao (2010) suggest that development of financial sector is likely to confer superior financial services for eco-friendly programs at decreased costs, and hence reduces energy pollutants. According to Tamazian (2009), an effective financial sector offers greater funding at lesser charges (which is equally valid for environmental projects too) and establishes a link between financial sector and environmental degradation.

McKinnon's conduit effect (1973) proposes that financial deepening results in poverty reduction. Rosner (2011) finds financial development as the effective direct source to achieve the first goal of MDGs i.e. to reduce poverty.

Mor and Ananth (2014) find two channels through which, financial development impacts health status: first is income/growth/returns channel and second is volatility/financial protection/risk channel. Ordonez (2012) finds that relationship between financial development and infant mortality is negative i.e., with improvements in the level of financial development infant mortality rate falls.

World Bank (World Bank, 2001b: 6) stresses on the role of financial sector in promoting economic growth. It also states that financial development can also have an indirect impact on the living standards of the poor through its role in 
promotion of economic growth. Evidences on the linkages between economic growth and sustainable development indicators shows that economic growth reduces poverty (Bourguignon, 2004).

Economic growth also "improves education by promoting school participation and gender equality by enabling women to control more of their own income, and health by increasing life expectancies and reducing child mortality rates" (Barro and Lee, 2001; The World Bank, 1993).

\section{DATA DESCRIPTION \& METHODOLOGY}

\subsection{Data Description}

Present study analyzes causal relationship between financial sector development and sustainable development in India, for the period 1980-2011. Financial sector development has been measured through a composite index by using Principal Component Analysis (PCA). Four alternative indicators of financial development that have been used for the index which are: Ratio of liquid liabilities to GDP ( $\mathrm{M}_{3}$ to GDP), Ratio of BSE market capitalization to GDP, Ratio of credit to private sector to GDP and Bank Density. We consider the following four indicators of sustainable development: (i) Per capita Gross National Income (PCGNI) is an indicator of poverty and income inequality, (ii) Gross Enrolment Ratio (GER) is the ratio of female gross enrolment ratio to male gross enrolment ratio for primary education, it shows the gender equality in the field of education (iii) Life Expectancy (LEXP) shows the number of years a newborn infant would live, if the prevailing pattern of morality will stay the same throughout its life. It shows the standard of health facility and hence the pattern of mortality exists in the country (iv) Carbon dioxide or $\mathrm{CO}_{2}$ (in per capita metric tons) is used to indicate the pace of environmental degradation in an economy. $\mathrm{CO}_{2}$ is the primary greenhouse gas emitted through human activities and it is responsible for the global warming \& climate change. Main sources of data are RBI Handbook of Statistics on Indian Economy and World Development Indicators (WDI), World Bank. Time series data from 1980 to 2011 is used in the study.

\subsection{Methodology}

The empirical analysis begins with the unit root test to check stationary of the time series. Augmented Dickey Fuller test (ADF-test)) has been used for the purpose

$$
\begin{aligned}
& \Delta Y_{t-1}=\beta+\delta y_{t-1}+\alpha_{i} \sum_{i=1}^{m} \Delta Y_{t-1}+\mu_{t} \\
& \Delta Y_{t}=\beta+\beta_{2} T+\delta Y_{t-1}+\alpha_{i} \sum_{i=1}^{m} \Delta Y_{t-1}+\mu_{t}
\end{aligned}
$$

Where,

$\mu=$ pure white noise error term, $\mathrm{m}$ is lag, $\beta$ is constant and $\Delta Y_{t}=\left(Y_{t-1}-Y_{t-2}\right), \Delta Y_{t-2}=\left(Y_{t-2}-Y_{t-3}\right)$ and so on.

The null hypothesis under the test is: $\mathrm{H}_{0}:=\delta=0$ (existence of unit root)

$\mathrm{H}_{1}:=\delta \neq 0$ (unit root does not exist)

After confirming the unit root properties of data, the long run relationship among the variables has been tested through Johansen-Juselius test of co integration

In order to assess the causal relation between variables, we used block erogeneity /Wald test, which look at 
whether the laws of any variables Granger cause any other variable in VAR/VECM. It determines bilaterally whether the lags of the excluded variable affect the endogenous variable by testing the null hypothesis that the lagged coefficients are significantly different from zero.

\section{EMPIRICAL RESULTS}

Table: 1 shows the estimated results of ADF - Test. It shows that at levels, high P-value associated with ADF test indicates failure to reject the null hypothesis of existence of unit-root. At first difference, the low probability values indicate the rejection of the null hypothesis. It is therefore concluded that, at these levels the variables are non-stationary. All the variables are stationary at first difference, hence integrated of order 1 i.e. I (1).

Table 1: Results of Unit Root Test

\begin{tabular}{|l|c|c|}
\hline \multirow{2}{*}{ Variable } & \multicolumn{2}{c|}{ ADF- Test } \\
\cline { 2 - 3 } & Test Statistic & Probability \\
\hline CO2 (Constant) & 1.709568 & 0.9994 \\
\hline CO2 (Constant \& Trend) & -4.158897 & 0.0154 \\
\hline$\Delta$ CO2 (Constant) & 2.568965 & 0.0024 \\
\hline$\Delta$ CO2 (Constant \& Trend) & 1.00687 & 0.03861 \\
\hline 1GER (Constant) & 0.120764 & 0.9623 \\
\hline GER (Constant \& Trend) & -2.476294 & 0.3366 \\
\hline$\Delta$ GER (Constant) & -5.222717 & 0.0002 \\
\hline$\Delta$ GER (Constant \& Trend) & -5.185985 & 0.0012 \\
\hline PCGNI (Constant) & 7.745578 & 1.0000 \\
\hline PCGNI (Constant \& Trend) & 2.301624 & 1.0000 \\
\hline$\Delta$ PCGNI (Constant) & -2.218247 & 0.2043 \\
\hline$\Delta$ PCGNI (Constant \& Trend) & -4.610107 & 0.0048 \\
\hline LEXP (Constant) & -8.106978 & 0.2361 \\
\hline LEXP (Constant \& Trend) & 2.009479 & 1.0000 \\
\hline$\Delta$ LEXP (Constant) & 0.601057 & 0.9869 \\
\hline$\Delta$ LEXP (Constant \& Trend) & 4.633533 & 0.0063 \\
\hline FINDEX (Constant) & 2.166606 & 0.9999 \\
\hline FINDEX (Constant \& Trend) & -0.504064 & 0.9776 \\
\hline$\Delta$ FINDEX (Constant) & -7.060218 & 0.0000 \\
\hline$\Delta$ FINDEX (Constant\& Trend) & -8.328396 & 0.0000 \\
\hline
\end{tabular}

MacKinnon (1996) one-sided p-values

Since the variables are I (1), the next step is to detect the co integration i.e. long - run relationship between the variables. For this, Johansen-Juselius test for co integration has been used. Johansen (1988) proposes two likelihood ratio tests for the co integration - trace test and Maximum Eigen value test. Results of both tests are reported in Table 3 to 6. Application of the test first requires determination of the order of VAR .Since the order of VAR cannot be known aprioi, Schwarz information criterion is used to determine the optimum lag length.

Table 2 reports the result of co integration between FINDEX and PCGNI and finds one co integrating equation at $95 \%$ confidence level.

Table 2: Results of Johansen Juselius Co Integration Test (FINDEX and PCGNI)

\begin{tabular}{|l|c|c|c|}
\hline Hypothesized no of CEs & Trace Statistics & 0.05 Critical Values & Probability** \\
\hline None* & 16.71542 & 15.49471 & 0.0326 \\
\hline At most 1 & 3.088782 & 3.841466 & 0.0788 \\
\hline Hypothesized no of CEs & Max - Eigen Values & 0.05 Critical Values & Probability** \\
\hline
\end{tabular}




\begin{tabular}{|l|c|c|c|}
\hline None* & 13.62663 & 14.26460 & 0.0629 \\
\hline At most 1 & 3.088782 & 3.841466 & 0.0788 \\
\hline
\end{tabular}

Trace test indicates 1 co integrating eqn (s) at the 0.05 level

Max-eigenvalue test indicates 1 co integrating eqn (s) at the 0.05 level

* denotes rejection of the hypothesis at the 0.05 level

**MacKinnon-Haug-Michelis (1999) p-values

In the initial estimation, no $\mathrm{Co}$ integration was found between financial development and $\mathrm{CO}_{2}$, and between financial development and GER. We therefore, test for Co integration between these two pairs of variables by taking economic growth as a mediating variable.

Table no. 3 shows the result of co integration among $\mathrm{CO}_{2}$, FINDEX and PCGNI. As per the trace and max eigen, two co integrating equations were found.

Table 3: Results of Johansen Juselius Co Integration Test ( $\mathrm{CO}_{2}$, FINDEX and PCGNI)

\begin{tabular}{|l|c|c|c|}
\hline Hypothesized no. of CE(s) & Trace Statistics & $\mathbf{0 . 0 5}$ Critical Value & Probability $^{* *}$ \\
\hline None & 32.34771 & 29.79707 & 0.0249 \\
\hline At most 1 * & 15.56524 & 15.49471 & 0.0488 \\
\hline At most 2 & 2.240891 & 3.841466 & 0.1344 \\
\hline Hypothesized no. of CE(s) & Max-Eigen Statistics & $\mathbf{0 . 0 5}$ Critical Value & Probability $^{* * *}$ \\
\hline None & 16.78247 & 21.13162 & 0.1825 \\
\hline At most 1 & 13.32435 & 14.26460 & 0.0700 \\
\hline At most 2 & 2.240891 & 3.841466 & 0.1344 \\
\hline
\end{tabular}

Trace test indicates 2 co integrating eqn (s) at the 0.05 level

Max-eigen value test indicates no co integration at the 0.05 level

* denotes rejection of the hypothesis at the 0.05 level

**MacKinnon-Haug-Michelis (1999) p-values

Table 4 reports the result of co integration among GER, FINDEX and PCGNI. The estimated results of trace and max eigen value shows one co integrating equation.

Table 4: Results of Johansen Juselius Co Integration Test (GER, FINDEX and PCGNI)

\begin{tabular}{|l|c|c|c|}
\hline Hypothesized no. of CE(s) & Trace Statistics & $\mathbf{0 . 0 5}$ Critical Value & Probability $^{* *}$ \\
\hline None* & 39.96869 & 29.79707 & 0.0024 \\
\hline At most 1 & 11.33811 & 15.49471 & 0.1915 \\
\hline At most 2* & 4.310556 & 3.841466 & 0.0379 \\
\hline Hypothesized no. of CE(s) & Max-Eigen Statistics & $\mathbf{0 . 0 5}$ Critical Value & Probability $^{* *}$ \\
\hline None* & 28.63058 & 21.13162 & 0.0037 \\
\hline At most 1 & 7.027554 & 14.26460 & 0.4859 \\
\hline At most 2* & 4.310556 & 3.841466 & 0.0379 \\
\hline
\end{tabular}

Trace test indicates 1 co integrating equation (s) at the 0.05 level

Max-eigen value test indicates 1 co integrating equation (s) at the 0.05 level

* denotes rejection of the hypothesis at the 0.05 level 
**MacKinnon-Haug-Michelis (1999) p-values

Table no. 5 reports the result of co integration between LEXP and FINDEX. As shown in the table trace and max, eigen value tests indicate one co integrating equation.

Table 5: Results of Johansen Juselius Co Integration Test (LEXP, FINDEX)

\begin{tabular}{|l|c|c|c|}
\hline Hypothesized no. of CE(S) & Trace Statistics & $\mathbf{0 . 0 5}$ Critical Value & Probability $^{* *}$ \\
\hline None* & 16.71542 & 15.49471 & 0.0326 \\
\hline At most 1 & 3.088782 & 3.841466 & 0.0788 \\
\hline Hypothesized no. of CE(S) & Max-Eigen Statistics & $\mathbf{0 . 0 5}$ Critical Value & Probability $^{* *}$ \\
\hline None* & 13.62663 & 14.26460 & 0.0429 \\
\hline At most 1 & 3.088782 & 3.841466 & 0.0788 \\
\hline
\end{tabular}

Trace test indicates 1 co integrating equation (s) at the 0.05 level

Max-eigen value test indicates 1 co integrating equation (s) at the 0.05 level

* denotes rejection of the hypothesis at the 0.05 level

**MacKinnon-Haug-Michelis (1999) p-values states the existence of co integrating relationships, which suggests there ought to be Granger causality in at least one direction. To determine the short run causality, Granger causality/Block Exogeneity Wald tests is used. Since the variables are found to be co integrated, the test is conducted in a VECM framework

Table 6: Vector Granger Causality/Block Exogeneity Wald Test

\begin{tabular}{|l|c|l|}
\hline \multicolumn{1}{|c|}{ Null Hypothesis } & Chi Square & \multicolumn{1}{c|}{ Decision } \\
\hline FINDEX does not cause PCGNI & $0.067834(0.045)$ & Reject \\
\hline PCGNI does not cause FINDEX & $1.497142(0.021)$ & Reject \\
\hline FINDEX does not cause LEXP & $15.545(0.003)$ & Reject \\
\hline FINDEX does not cause GER & $0.01330(0.9082)$ & Do not Reject \\
\hline PCGNI does not cause GER & $1.4406(.22)$ & Do not Reject \\
\hline FINDEX does not cause CO2 & $7.2042(.065)$ & Do not Reject \\
\hline PCGNI does not cause CO2 & $4.01(.25)$ & Do not Reject \\
\hline
\end{tabular}

The above table reports the results of VEC based Granger causality. As revealed by the table, there exists a bidirectional causation between PCGNI and FINDEX as the hypothesis of FINDEX not causing PCGNI, and PCGNI not causing FINDEX that stand rejected at 5\% level of significance, which implies that poverty reduction requires financial development, but at the same time, the degree of financial development is caused by the growth of per capita GNI.

There runs a unidirectional causation from FINDEX to LEXP showing that financial development may be effective in securing better health outcomes. The causation between FINDEX and GER and between FINDEX and CO2 was detected in presence of economic growth. The causality results obtained indicate an absence of causation from FINDEX to GER. Also, the null hypothesis of FINDEX not causing CO2 can be rejected only at $10 \%$ level indicating a weak direct causation from financial development to environmental outcomes.

\section{CONCLUSIONS \& POLICY IMPLICATIONS}

The objective of the present study is to empirically examine the link between financial development and selected indicators of sustainable development in India, during 1980 to 2011. Towards this objective, Johansen-Juselius test of co integration and Granger Causality Test have been used. Study focused on four indicators related to sustainable 
development goals namely, poverty, health, gender equality and climate change out of the 17 goals proposed by United Nation (2015). Financial development has been measured by a composite index using Principal component analysis. Study finds that financial development causes life expectancy, and there exists bidirectional causal relationship between financial development and per capita income. However, there exists weak direct causation from financial development to environmental outcomes and absence of causation between financial development and gross enrolment ratio.

Our results suggest that, whereas financial development can be used as an effective tool in realising desired health outcomes, its impact on gender equality are rather limited, therefore, government should facilitate the development of financial sector for the better health outcomes in the economy. Financial development might be used for poverty reduction, but the bidirectional causality also reflects the fact that financial development is not exogenous, and is probably constrained by the level of poverty in the economy.

\section{REFERENCES}

1. Barro, R. \& J.W. Lee. (2001) International Data on Educational Attainment: Updates and Implications', Oxford Economic Papers, 53(3).

2. Barro, R.J., \& Lee, J.W., (2001) Schooling Quality in a Cross-Section of Countries. Economica, 68 (271), 465-488.

3. Bourguignon, F., (2004) the Poverty-Growth-Inequality Triangle. Indian Council for Research on International Economic Relations, 69.

4. Bourguignon, F. et al. (2008) Millennium Development Goals at Midpoint: Where Do We Stand and Where Do We Need To go?. Research Paper for the European Commission.

5. Claessens, S., \& Feijen, E. (2007) financial sector development and the millennium development goals. World Bank Working Paper, vol. 89. The World Bank

6. Engle, R.F., \& Yoo, B.S. (1987) Forecasting and Testing in Co integrated system. Journal of Econometrics, Vol. 35, p. 143159.

7. Engle, R.F., \& Granger, C.W.J. (1987) Co integration and Error Correction, Representation, Estimation, and Testing. Econometric: Journal of the Econometric Society, 55, 251-276.

8. Feachem, R. G. (1994) World Development Report 1993: Investing in health. Journal of Public Health, 16(2), 129-131

9. Granger, C. W. (1969) Investigating causal relations by econometric models and cross-spectral methods. Econometric: Journal of the Econometric Society, 424-438.

10. Halicioglu, F. (2009) an econometric study of CO2 emissions, energy consumption, income and foreign trade in Turkey. Energy Policy 37 (3), 1156-1164.

11. Levine, R., (2004) Finance and Growth: Theory and Evidence. National Bureau of Economic Research, Working Paper 10766.

12. Mundial, B. (1993) World development report 1993; investing in health. Oxford University Press

13. Rosner, B., (2010) the Impact of Financial Development on Poverty in Developing Countries. UCLA Undergraduate Journal of Economics. 1 (2).

14. Tamazian, A. et al. (2009) Does higher economic and financial development lead to environmental degradation: evidence from BRIC countries. Energy Policy, 37 (1), 246-253.

15. Tamazian, A., \& Rao, B. B. (2010) Do economic, financial and institutional developments matter for environmental 
degradation? Evidence from transitional economies. Energy Economics, 32 (1) 137-145.

16. The UN Millennium Project, (2005) Investing in Development: A Practical Plan to Achieve the Millennium Development Goals. The United Nations Development Programme.

17. The World Bank, (1993). World Development Report 1993: Investing in Health. The International Bank for Reconstruction and Development/the World Bank. 